Annisa Friska Safa \& Eri Kurniawan, Gordon Ramsay's Politeness Strategies

\title{
GORDON RAMSAY'S POLITENESS STRATEGIES IN MASTERCHEF AND MASTERCHEF JUNIOR US
}

\author{
Annisa Friska Safa \\ Eri Kurniawan \\ Departemen Bahasa dan Sastra Inggris FPBS UPI \\ Address: Jl. Dr. Setiabudhi 229 Bandung 40154 \\ E-mail: erikurn@gmail.com
}

\begin{abstract}
This research aims to investigate the types of politeness strategies that are performed by Gordon Ramsay in judging the Masterchef US and Masterchef Junior US contestants' dishes and to reveal whether Gordon Ramsay performs any different politeness strategies between the Master chef and Masterchef Junior contestants. The data spring from Gordon Ramsay utterances, taken from the elimination test of two episodes of Masterchef season 4 (episode 9 and 12) and the elimination test of two episodes of Masterchef Junior US season 1 (episode 2 and 6). The framework of Brown \& Levinson's (1987) politeness strategies is adopted. Findings reveal that Gordon Ramsay performed bald on-record strategy, positive politeness, and off record strategy. Furthermore, Ramsay performed diferent varieties of politeness strategies in Masterchef; and performed only positive politeness strategy in Masterchef Junior.
\end{abstract}

Keywords: politeness strategies, masterchef, masterchef junior, Gordon Ramsay

\begin{abstract}
Abstrak
Penelitian ini bertujuan untuk menyelidiki tipe strategi kesopanan yang dilakukan oleh Gordon Ramsay saat menilai masakan dari kontestan Masterchefdan Masterchef Junior US dan untuk mengungkapkan adakah perbedaan strategi kesopanan yang dilakukan Gordon Ramsay kepada kontestan Masterchef US dan Masterchef Junior US. Data penelitian ini berupa tuturan Gordon Ramsay yang diambil dari tes eliminasi dalam dua episode Masterchef US musim ke-4 (episode 9 dan 12), dan dua episode Masterchef Junior US musim pertama (episode 2 dan 6). Teori yang digunakan adalah teori strategi kesopanan milik Brown dan Levinson (1987). Hasil temuan menunjukkan bahwa Gordon Ramsay melakukan strategi kesopanan bald-on record, strategi kesopanan positif, danstrategi kesopanan off record. Lebih lanjut, Gordon Ramsay melakukan lebih banyak variasi strategi kesopanan di Masterchef, sebaliknya, Gordon Ramsay hanya melakukan strategi kesopanan positif di Masterchef Junior.
\end{abstract}

\section{Kata-kata kunci: Strategi Kesopanan, Masterchef, Masterchef Junior, GordonRamsay}

\section{INTRODUCTION}

Nowadays, competitions or talent shows of varying nature are mushrooming on television, such as dancing, singing, modelling, even a cooking show. After the contestants of those competition show their abilities, the judges give them comments. Not only the contestants performances, but also judges' comments on contestants are interesting to see. One of the talent shows which attracts the audience because of the judges' comments is Masterchef US. It is hard to deny that the judges' comments influence the contestants' cooking, where they have 
to give their best meal every week. Judges' comments could be congratulating, compliments, suggestions, even scrutiny. One of the Masterchef US judges who often supplies critical commentsis Gordon Ramsay.

Gordon Ramsay is one of the judges of Masterchef, and its spin off, Masterchef Junior US who plays the antagonist role to criticize the contestants' dishes. Masterchef US is a cooking contest for young adults/adult amateurs and home chefs.On the other hand, Masterchef Junior US is a cooking contest forkids aged 9 to 12 years old.It is interesting to see whether Gordon Ramsay performs any different treatment to the contestants.In judging a dish, Gordon Ramsay needs to perform certain strategies in order to save the contestants' face. Because if the evaluation is negative, it could be potentially to threat the contestants' face. Variables such as social distance, age difference, institutional setting and power have contributed to the different choice of politeness strategies (Senowarsito, 2013).While variable age has relative effect on performing politeness strategies (Safavi \& Zamanian, 2014).

According to Brown Levinson, as cited in Thomas (1995), some acts could damage or threaten a person's face. These acts are known as face-threatening acts (FTA), such as complaints, criticisms, disagreement, insults. Brown and Levinson (1987) defined FTA based on two variables: i) whose face is being threatened (the speaker's or the hearer's), and ii) which type of face is being threatened (positive or negative). Based on the intensity of the threats, there are five politeness strategies. The five strategies are sorted by degree of risk of 'losing face'. Those strategies arebald onrecord, positive politeness, negative politeness, off record and do not perform FTA (Thomas, 1995).

Bald on-record is a strategy where the speaker tends to say something clearly. It does not attempt to minimize the threat to the hearer's face. Brown \& Levinson (1987) state that most speaker perform bald on-record when he wants to do FTA with the maximum efficiency. Brown \& Levinson (1987) divide bald onrecord into two sub-strategies:i) casesof non-minimization of the threat, and ii) cases of FTA-oriented bald on-record usage.

Positive politeness strategy is a strategy where the speaker wants to satisfy the hearer's wants or keeps the positive of the hearer's face (Brown \& Levinson, 1987). Brown \& Levinson (....) also outline the sub strategies of politeness strategies: (1) Notice, attend to $\mathrm{H}$ (interest, wants, needs, goods); (2) Exaggerate (interest, approval, sympathy to $\mathrm{H}$ ); (3) Intensify interest to $\mathrm{H}$; (4) Use in-group identity marker; (5) Seek agreement; (6) Avoid disagreement; (7) Presuppose/raise/assert common ground; (8) Joke; (9) Assert or presuppose S's knowledge of and concern for H's wants; (10) Offer, promise; (11) Be optimistic; (12) Include both $\mathrm{S}$ and $\mathrm{H}$ in the activity; (13) Give (or ask for) reasons; (14) Assume or assert reciprocity; (15)Give gifts to $\mathrm{H}$ (goods, sympathy, understanding, cooperation)

Negative politeness is a strategy of saving negative face of the hearer. This strategy ascertains the speaker recognizes and respects the hearer's face; wants and will not distract the hearer's freedom of action (Brown \& Levinson, 1987) Negative politeness is classified into ten sub-strategies: 
1. Be conventionally indirect

2. Question, hedge

3. Be pessimistic

4. Minimize the imposition

5. Give deference

6. Apologize

7. Impersonalize $\mathrm{S}$ and $\mathrm{H}$ (Avoid the pronouns 'I' and 'You')

8. State the FTA as general rule

9. Nominalize

10. Go on record as incurring a debt, or as not indebting $\mathrm{H}$

According to Brown and Levinson (1987), off record strategy is a strategy in which the speaker doesan FTA indirectly and lets the hearer freely interpret it. Off record strategy is divided into 15 substrategies:

1. Give hints

2. Give association clues

3. Presuppose

4. Undrestate

5. Overstate

6. Use tautologise

7. Use contradictions

8. Be ironic

9. Use metaphor

10. Use rhetorical questions

11. Be ambigous

12. Be vague

13. Over-generalize

14. Displace H

15. Be incomplete, use elipsis

Previous studies have examined politeness strategies in different media. Utami, et al.(2013), for example, analyzed politeness strategies in realisation of expressive speech acts in X-Factor Indonesia Talent Show. They showed that the X-Factor judges performed positive politeness, bald on record and off record. Wise (2011) analyzed the different politeness strategies between English and Spanish magazine advertisements. The study showed that English magazines tend to use negative politeness, whereas Spanish ones prefer positive politeness. This present study compares two identical TV shows that differ minimally in age of participants, which is expected to influence the way one realizes politeness. It aims to investigate the types of politeness strategies performed by Gordon Ramsay in judging the Masterchef and Masterchef Junior contestants' dishes and to reveal whether Gordon Ramsay performs different politeness strategies when interacting with the Masterchef and Masterchef Junior contestants.

\section{METHOD}

This study primarily applies a descriptive-qualitative method. The qualitative method is an appropriate method because the study involves words rather than numbersand in-depth elaboration of findings and analysis. The descriptive method is considered as most suitable since it aims to answer the question about the 'what' of a phenomenon (Green, 2007). The data are Gordon Ramsay's utterances, taken from the elimination test of two episodes of Masterchef season 4 (episode 9 and 12) and elimination test of two episodes of Masterchef Junior US season 1 (episode 2 and 6). The data are gained from a subtitle trancript which is downloaded from htpp://tinysub.net. The data are then split into chunks of utterances, and then classified based on Brown and Levinson's politeness strategies and comparison among them is then made. 


\section{RESULTS AND DISCUSSIONS}

This section delineates findings and their analysis as regards the kinds of politeness strategy Gordon Ramsay employed in two identical TV shows, i.e. Masterchef US and MasterchefJunior US. The following is a table that illustrates comparison of politeness strategies used by Ramsay.

Table 1. The result of using Politeness Strategies by Gordon Ramsay

\begin{tabular}{lccccc} 
& $\begin{array}{c}\text { Bald on- } \\
\text { record }\end{array}$ & $\begin{array}{c}\text { Positive } \\
\text { Politeness }\end{array}$ & $\begin{array}{c}\text { Negative } \\
\text { Politeness }\end{array}$ & Off record & Total \\
Masterchef & 5 & 7 & 0 & 4 & 16 \\
\hline Masterchef Jr & 0 & 14 & 0 & 0 & 14 \\
\hline \hline Total & $\mathbf{5}$ & $\mathbf{2 1}$ & $\mathbf{0}$ & $\mathbf{4}$ & $\mathbf{3 0}$ \\
\hline Percentage & $17 \%$ & $70 \%$ & $0 \%$ & $13 \%$ & $100 \%$ \\
\hline
\end{tabular}

Table 1 shows the realization politeness strategy by Gordon Ramsay in Masterchef and Masterchef Junior US. The most frequent of politeness strategy used by Gordon Ramsay in Masterchef US and Masterchef Junior US is positive politeness strategies. However, Ramsay tends to perform more variations of politeness strategies to Masterchef contestants.By contrast, Gordon Ramsay only performs positive politeness strategies to Masterchef Junior contestants.

Table 2. The Detail of the Realization of Using Politeness Strategy by Gordon Ramsay

\begin{tabular}{lcccc}
\hline \multicolumn{1}{c}{ Strategies } & Masterchef & Percentage & $\begin{array}{c}\text { Masterchef } \\
\text { Junior }\end{array}$ & Percentage \\
\hline $\begin{array}{l}\text { Bald on record -Cases of non- } \\
\text { minimization of the threat }\end{array}$ & 5 & $31 \%$ & - & $0 \%$ \\
\hline $\begin{array}{l}\text { Positive Politeness -Notice, } \\
\text { attend to H (interest, wants, } \\
\text { needs, goods) }\end{array}$ & - & $0 \%$ & 1 & $7 \%$ \\
\hline $\begin{array}{l}\text { Positive Politeness -Exaggerate } \\
\text { interest, approval, sympathy } \\
\text { with H) }\end{array}$ & 2 & $13 \%$ & 3 & $21 \%$ \\
\hline $\begin{array}{l}\text { Positive Politeness -intensify } \\
\text { interest to H }\end{array}$ & - & $0 \%$ & 2 & $14 \%$ \\
\hline $\begin{array}{l}\text { Positive Politeness - use-in group } \\
\text { identity marker }\end{array}$ & - & $0 \%$ & 2 & $14 \%$ \\
\hline $\begin{array}{l}\text { Positive Politeness - seek } \\
\text { agreement }\end{array}$ & - & $0 \%$ & 1 & $7 \%$ \\
\hline $\begin{array}{l}\text { Positive Politeness -assert S's } \\
\text { knowledge of and concern for }\end{array}$ & 2 & $13 \%$ & - & $0 \%$ \\
H's wants & & & 1 & $7 \%$ \\
\hline $\begin{array}{l}\text { Positive Politeness -give (or ask } \\
\text { for) reasons }\end{array}$ & 2 & $13 \%$ & & \\
\hline
\end{tabular}




\begin{tabular}{lllll}
\hline Positive Politeness-Be optimistic & 1 & $6 \%$ & - & $0 \%$ \\
\hline $\begin{array}{l}\text { Positive Politeness -Give gifts to } \\
\mathrm{H} \quad \text { (sympathy, understanding, } \\
\text { cooperation) }\end{array}$ & - & $0 \%$ & 4 & $29 \%$ \\
\hline Off record -Use contradictions & 1 & $6 \%$ & - & $0 \%$ \\
\hline Off record-Be ironic & 1 & $6 \%$ & - & $0 \%$ \\
\hline $\begin{array}{l}\text { Off record -use rhetorical } \\
\text { question }\end{array}$ & 2 & $13 \%$ & - & $0 \%$ \\
\hline Total & $\mathbf{1 6}$ & $\mathbf{1 0 0 \%}$ & $\mathbf{1 4}$ & $\mathbf{1 0 0 \%}$ \\
\hline
\end{tabular}

Table 2 shows the politeness strategies with its sub strategies. The sub strategies of positive politeness strategies used by Gordon Ramsay in Masterchef are Exaggerate (interest, approval, sympathy with $H$ ), intensify interest to $H$, assert S's knowledge of and concern for H's wants, and give (or ask for) reasons. While, in Masterchef Junior is give gifts to $\mathrm{H}$ (sympathy, understanding, cooperation sub strategy. The data analysis based on the classification of table 1 and 2 as follows:

\section{Masterchef US}

\section{$\underline{\text { Bald on-record }}$}

(1) This a conversation between Gordon Ramsay (GR) and Bethy (B), 28 years old, in elimination test of Masterchef US Season 4, $10^{\text {th }}$ episode. Bethy cooked a lime meringue pie.

GR: (taste the pie) badly/ thought out//

The pastry/ is/ raw/ there/ (Showing the raw pastry)

I/ knew/ you/ were [bleep]/ the minute/ you/ put/ that/ curd/ on top of/ a/ raw/ pastry/ what/ a/ mess/ (leaving Bethy)

The realization of politeness strategies in data (1) is marked by the bald on-record with cases of non-minimization of the threat sub strategy as shown by the bold sentence. The speaker shows his disappointment directly to the hearer by saying, "I knew you were [bleep] the minute you put that curd on top of a raw pastry. What a mess."

Positive Politeness - Exaggerate (interest, approval, sympathy with $\mathrm{H}$ )

(2) This a conversation between Gordon Ramsay (GR) and Lynn (L), 27 years old, in elimination test of Masterchef US season $4,12^{\text {th }}$ episode. Lynn cooked raspberry macaroons and vanilla bean macaroons, and put them in a box.

GR: Lynn/ how/ tough/ was/ that/ pressure/ test/?

L: It's/ the/ toughest/ thing/ I've/ ever/ baked//

GR: So/ you/ didn't/ manage/ 12/ in/ the/ box//

L: I/ didn't//

GR: Why/ not//?

L: I/ piped/ the/ macaroons/ way/ too/ thick//

GR: What's/ inside/ the/ box//?

L: Five/ raspberry/ macaroons/ and/ five/ vanilla/ bean/ macaroons//

GR: Visually/ yeah/ it's/ got/ that/ "wow"/ factor/ definitely/

(Cut the macaroon) Beautiful/ 
The realization of politeness strategies in data (2) is marked by the positive politeness with Exaggerate (interest, approval, sympathy with H) sub strategy as shown by the bold sentence. The speaker shows his satisfaction exaggeratedly.

Positive Politeness - assert S's knowledge of and concern for H's wants

(3) This a conversation between Gordon Ramsay (GR) and Lynn (L), 27 years old, in elimination test of Masterchef US season $4,12^{\text {th }}$ episode. Lynn cooked raspberry macaroons and vanilla bean macaroons, and put them in a box.

GR: Lynn/ how/ tough/ was/ that/ pressure/ test/?

L: It's/ the/ toughest/ thing/ I've/ ever/ baked//

GR: So/ you/ didn't/ manage/ 12/ in/ the/ box//

\section{L: I/ didn't//}

GR: Why/ not//?

L: I/ piped/ the/ macaroons/ way/ too/ thick//

GR: What's/ inside/ the/ box//?

L: Five/ raspberry/ macaroons/ and/ five/ vanilla/ bean/ macaroons//

GR: Visually/ yeah/ it's/ got/ that/ "wow"/ factor/ definitely// (L1)

(Cut the macaroon) Beautiful//

(Eat one of the macaroons) That's/ interesting// It's/ actually/ a/ little/ bit/ too/ sweet// I/ mean/ the/salted/ caramel/ works/ but/ if/ you're/ putting/ that/ filling/ in/ there/ then/ you/ just/ pull/ back/ three/ or/ four/ grams/ on the/ sugar/ especially/ in/ the/ meringue// Cause/ you/ got/ the/ sugar/ syrup//

(Eat another one) "Nice/ idea/ but/ the/ golden/ rule/ of/ any/ macaroon/ is/ that/ you/ don't/ put/ fruit/ inside//

The realization of politeness strategies in data (3) is marked by the positive politeness with assert S's knowledge of and concern for H's wants sub strategy as shown by the bold sentence. The speaker shows that he knew what the hearer planned to and then give the hearer a suggestion.

Positive Politeness - give (or ask for) $\underline{\text { reasons }}$

(4) This is a conversation between Gordon Ramsay (GR) and Jonny (Jo), 28 years old, in elimination test of Masterchef US season $4,12^{\text {th }}$ episode. He cooked chocolate macaroons with a peanut butter mousse and vanilla macaroons with a raspberry mascarpone filling, and put them in the box.

GR: Okay// so/ tell/ me/ the/ flavors/ inside/ that/ box//?

Jo: There's/ a/ chocolate/ macaroon/ with/ a/ peanut/ butter/ mousse/ and/ there's/ a/ vanilla/ macaroon/ with/ a/ raspberry/ mascarpone/ filling//

GR: Good// (Open the box slowly) (sigh) come/ on// what/ happened//?

Jo: My/ batter/ was/ a/ little/ thicker/ consistency/ than/ I/ thought/ it/ was/ gonna/ be// and/ I-I/ expected/ 'em/ to/ settle/ a/ little/ more// so/ when/ I/ baked/ 'em/ they/ were/ just// they/ were/ way/ too/ tall/ to/ get/ 'em/ in/ the/ box/ but/ I/ thought/ we/ had/ to/ have/ all/ $12 / \mathrm{in} /$ the/ box/ or/ it/ was// 
The realization of politeness strategies in data (4) is marked by the positive politeness with give (or ask for) reasons sub strategy as shown by the bold sentence. The speaker is disappointed but he wants to know the reason of the hearer cooked badly.

$\underline{\text { Positive Politeness - Be optimistic }}$

(5) This is a conversation between Gordon Ramsay (GR) and Jonny (Jo), 28 years old, in elimination test of Masterchef US season $4,12^{\text {th }}$ episode. He cooked chocolate macaroons with a peanut butter mousse and vanilla macaroons with a raspberry mascarpone filling, and put them in the box.

GR: Okay// so/ tell/ me/ the/ flavors/ inside/ that/ box//?

Jo: There's/ a/ chocolate/ macaroon/ with/ a/ peanut/ butter/ mousse/ and/ there's/ a/ vanilla/ macaroon/ with/ a/ raspberry/ mascarpone/ filling//

GR: Good// (Open the box slowly) (sigh) come/ on// what/ happened//?

Jo: My/ batter/ was/ a/ little/ thicker/ consistency/ than/ I/ thought/ it/ was/ gonna/ be// and/ I-I/ expected/ 'em/ to/ settle/ a/ little/ more// so/ when/ I/ baked/ 'em/ they/ were/ just// they/ were/ way/ too/ tall/ to/ get/ 'em/ in/ the/ box/ but/ I/ thought/ we/ had/ to/ have/ all/ 12/ in/ the/ box/ or/ it/ was//

GR: So/ did/ he (Lynn)// I'd/ rather/ taste/ nine/ delicious/ macaroons/ than/ jamming/ them/ in/ there//

The realization of politeness strategies in data (5) is marked by the positive politeness with be optimistic sub strategy as shown by the bold sentence. The speaker shows that if the hearer would put the macaroons nicely, he would taste it happily.

Off Record - Use contradictions

(6) This is a conversation between Gordon Ramsay (GR) and Jonny (Jo), 28 years old, in elimination test of Masterchef US season $4,12^{\text {th }}$ episode. He cooked chocolate macaroons with a peanut butter mousse and vanilla macaroons with a raspberry mascarpone filling, and put them in the box.

GR: Okay// so/ tell/ me/ the/ flavors/ inside/ that/ box//?

Jo: There's/ a/ chocolate/ macaroon/ with/ a/ peanut/ butter/ mousse/ and/ there's/ a/ vanilla/ macaroon/ with/ a/ raspberry/ mascarpone/ filling//

GR: Good// (Open the box slowly) (sigh) come/ on// what/ happened//?

Jo: My/ batter/ was/ a/ little/ thicker/ consistency/ than/ I/ thought/ it/ was/ gonna/ be// and/ I-I/ expected/ 'em/ to/ settle/ a/ little/ more// so/ when/ I/ baked/ 'em/ they/were/ just// they/ were/ way/ too/ tall/ to/ get/ 'em/ in/ the/ box/ but/ I/ thought/ we/ had/ to/ have/ all/ 12/ in/ the/ box/ or/ it/ was//

GR: So/ did/ he (Lynn)//

I'd/ rather/ taste/ nine/ delicious/ macaroons/ than/ jamming/ them/ in/ there// you've/ got/ the/ colors/ right// It/ looks/ like/ the/ piping/ nozzle/ was/ way/ too/ small//

(Take one of the macaroons) So/ therefore/ you/ created/ too/ much/ height/ as/ opposed/ to/ too/ much/ girth// visually/ you've/ got/ the/ ratio/ right//

(Cut the macaroon) They/ cut/ beautifully// See/ that/ little/ lip/ there//? 
You've/ got/ the/ nice/ crisp/ edge/ and/ that/ soft/ gooey/ center// (Eat the macaroon) that/ tastes/ delicious/ chewy/ flavorsome// But/ it's/ just/ the/ end//

The realization of politeness strategies in data (6) is marked by the off record with use contradiction sub strategy as shown by the bold sentence. The speaker shows the contradictive that the macaroon is delicious, but unfortunately it is broken because the hearer force the macaroons to fit into box.

\section{Off Record - Use Rhetorical Questions}

(7) This is a conversation between Gordon Ramsay (GR) and Bime $(\mathrm{Bm}), 32$ years old, in elimination test of Masterchef US Season 4, $10^{\text {th }}$ episode. He cooked a lime meringue pie.

GR: Okay/ Bime/ (come to Bime)

(Cutting the pie) Oh/ dear// Bime/ what/ have/ you/ done/ here//?

(Take out a piece of pie) $\mathrm{Ah} / / \mathrm{Well} /$ I/ mean//

\section{Bm: Curd/ didn't/ set// Didn't//}

GR: [bleep]// (leaving Bime to take a couple of cocktail glass)

You've// been// to/ a/ cocktail/ bar/, right//? (Pouring out the curd into the cocktail glass)

Cheers/ good/ health// (Drink the curd)

[Bleep]/ Me// (Cough) what/ is/ that/ in/ there//? What's/ the/ grainy/ bits//?

Bm: Cream/ of tartar// I/ missed up// I/ grabbed/ the wrong/ thing/ and/ I/ just/ started/ throwing/ it/ in/ there//
GR: What/ are/ you/ trying to/ do/ kill/ us//?

The realization of politeness strategies in data (7) is marked by the off record with rhetorical questions sub strategy as shown by the bold sentence. The speaker shows how bad the food is by questioning it rather than saying it directly.

\section{Off Record - Be Ironic}

(8) This is a conversation between Gordon Ramsay (GR) and Bime $(\mathrm{Bm}), 32$ years old, in elimination test of Masterchef US Season 4, $10^{\text {th }}$ episode. He cooked a lime meringue pie.

GR: Okay/ Bime/ (come to Bime)

(Cutting the pie) Oh/ dear// Bime/ what/ have/ you/ done/ here//?

(Take out a piece of pie) Ah// Well/ I/ mean//

Bm: Curd/ didn't/ set// Didn't//

GR: [bleep]//(leaving Bime to take a couple of cocktail glass)

You've// been// to/ a/ cocktail/ bar/, right//? (Pouring out the curd into the cocktail glass)

Cheers/ good/ health// (Drink the curd)

[Bleep]/ Me// (Cough) what/ is/ that/ in/ there//? What's/ the/ grainy/ bits//?

Bm: Cream/ of tartar// I/ missed up// I/ grabbed/ the wrong/ thing/ and/ I/ just/ started/ throwing/ it/ in/ there//

GR: What/ are/ you/ trying to/ do/ kill/ us//? In/ the/ recipe/ it's/ like/ a/ teaspoon// How/ many/ tablespoons//?

Bm: Like/ almost/ like/ ten// 
GR: Ten//?

Bm: Cause/ I'm/ like/ time/ is/ running out//

GR: Time's/ running/ out//? Yeah/ something's/ running/ through/ my/ [bleep]/ now//

The realization of politeness strategies in data (8) is marked by the off record with be ironic sub strategy as shown by the bold sentence. The speaker shows how bad the food is by being ironic rather than saying it directly.

\section{Masterchef Junior US}

Positive Politeness - Exaggerate ((interest, approval, sympathy with $\mathrm{H}$ )

(9) This is a conversation between Gordon Ramsay (GR) and Alexander (A), 13 years old, in elimination test of Masterchef Junior Season 1, $2^{\text {nd }}$ episode. He cooked beef sliders with black garlic aioli.

GR: That/ has/ to be/ one/ of the most/ attractive/ sliders/ anywhere/ in/ the/ country/ tonight// Great/ job//

A: Thank/ you//

GR: So/ why/ the/ kale//?

A: I/ think/ it's/ like/ a/ really/ nice/ alternative/ than/ using/ potatoes//

(GR eat the burger) I/ really/ like/ going/ outside/ of the/ box/ and/ making/ things/ really/ different/ and/ it's/ also/ like/ a/ lighter/ option//

GR: Burger's/ delicious// they/ taste/ as good as/ they/ look/ and/ they've/ got/ that/ star- quality//

The realization of politeness strategies in data (9) is marked by the positive politeness with Exaggerate (interest, approval, sympathy with $\mathrm{H}$ ) sub strategy as shown by the bold sentence. The speaker shows his satisfaction exaggeratedly

Positive Politeness - intensify interest to $\underline{\mathrm{H}}$

(10) This is a conversation between Gordon Ramsay (GR) and Jack (Jc), 10 years old, in elimination test of Masterchef Junior US Season 1, $6^{\text {th }}$ episode. He cooked a chicken breast roullade with goat cheese.

GR: Long/ island/ Jack// Right/ young/ man// Look/ at/ that/ beauty// Jack/ what/ is/ that $/ /$ ?

Jc: Chicken/ breast/ roulade/ stuffed/ with/ goat/ cheese/ sun-dried/ tomatoes/ and/ chopped/ olives/ wrapped/ in/ prosciutto/ with/ grilled/ asparagus/ and/ roasted/ potatoes//

GR: Visually/ it/ looks/ beautiful// Just/ remind/ me/ again/ how/ old/ you/ are//

Jc: I'm/ ten/ years/ old//

GR: Wow// Uh/ look/ seriously/ when/ we/ heard/ you/ were/ doing/ a/ roulade/ one/ of/ the/ most/ difficult/ things/ to/ accomplish// Why/ are/ you/ being/ so/ adventurous//?

Jc: I/ like/ being/ very/ ambitious/ and/ unique// and/ I/ like/ blowing/ people/ away/ with/ my/ food//

GR: (eat the dish) Uh/ Jack/ I'm// I'm/ lost/ for/ words/ young/ man//

Jc: Thank/ you/ chef//

GR: I'm/ lost/ for/ words// the/ dish/ is/ delicious// the/ prosciutto/ is/ crispy// the/ chicken/ is/ moist// Pounding it/ rolling/ it/ wrapping/ it/ cooking/ it/ so/ technical// If/ this/ is/ what/ you're/ like/ at/ 10/ god/ help/ our/ industry/ when/ you're/ 20// 
The realization of politeness strategies in data (10) is marked by the positive politeness with Exaggerate (interest, approval, sympathy with $\mathrm{H}$ ) sub strategy as shown by the bold sentence. The speaker wants to communicate to intensify his interest by 'making a good story'.

Positive Politeness - Notice, attend to $\mathrm{H}$ (interest, wants, needs, goods)

(11) This is a conversation between Gordon Ramsay and Troy (Tr), 12 years old, in elimination of Masterchef Junior US season $1,6^{\text {th }}$ episode. He cooked a chicken thigh with romesco sauce.

GR: Wow/ So/ Troy/ what/ is/ that//?

Tr: A/ pan-fried/ chicken/ thigh/ with/ romesco/ sauce/ and/ spaghetti/ squash/ and/ zucchini/ salad//

GR: Visually/ it/ looks/ beautiful// I/ was/ slightly/ concerned/ it/ was/ all/ gonna/ look/ slightly/ beige-y/ but/ you've/ got/ that/ vibrancy/ from/ the/ sauce//

Tr: Thank/ you//

GR: What's/ around/ the/ outside/ here//?

Tr: Um/ that's/ herb/ oil/ with/ olive/ oil/ parsley/ and/ a/ little/ cilantro/ in/ there//

GR: (eat the garnish and the sauce) Wow// that/ sauce/ is/ so/ fresh// so/ delicious/ got/ that/ vibrancy// It's/ got/ that/ richness/ to/ it// and/ how/ long/ did/ you/ cook/ the/ chicken/ for//?

Tr: I/ cooked/ it/ about/ four/ minutes/ on/ each/ side/ in/ the/ sauté/ pan/ and/ then/ I/ put/ it/ in/ the/ oven/ and/ baked/ it/ for/ about/ seven/ minutes//

GR: Now/ slice/ that/ through/ (slice the chicken) $\mathrm{Oh} /$ dear//
Tr: What//?

GR: Damn/ damn/ damn/ damn/ damn// I/ can't/ even/ taste/ the/ side/ of/ it/ because/ you/ can/ see/ it's/ still/ raw//

Tr: Yes/ I/ know//

GR: Uh/ oh/ young/ man/ I'm/ so/ disappointed//

Tr: $\mathrm{Me} / \mathrm{too} / /$

GR: A/ thigh/ takes/ a/ minimum/ of/ 20/ to/ 25/ minutes/ in/ the/ oven// A/ breast/ is/ so/ much/ easier/ to/ cook// you've/ done/ so/ well/ in/ this/ competition// I/ did/not/ expect/ you/ to/ serve/ $\mathrm{me} / \mathrm{an} / \mathrm{undercooked} / \mathrm{chicken} / /$ what/ a/ shame// Damn//

The realization of politeness strategies in data (11) is marked by the positive politeness with notice, attend to $\mathrm{H}$ (interest, needs, wants, goods) sub strategy as shown by the bold sentence. The speaker wants to criticize the hearer, but to save his positive face, the speaker decides to compliment the hearer first.

Positive Politeness - use in-group identity marker

(12) This is a conversation between Gordon Ramsay (GR) and Jack (Jc), 10 years old, in elimination test of Masterchef Junior US Season 1, $6^{\text {th }}$ episode. He cooked a chicken breast roullade with goat cheese.

GR: Long/ island/ Jack// Right/ young/ man// Look/ at/ that/ beauty// Jack/ what/ is/ that//?

Jc: Chicken/ breast/ roulade/ stuffed/ with/ goat/ cheese/ sun-dried/ tomatoes/ and/ chopped/ olives/wrapped/ in/ prosciutto/ with/ grilled/ asparagus/ and/ roasted/ potatoes// 
GR: Visually/ it/ looks/ beautiful// Just/ remind/ me/ again/ how/ old/ you/ are//

Jc: I'm/ ten/ years/ old//

GR: Wow// Uh/ look/ seriously/ when/ we/ heard/ you/ were/ doing/ a/ roulade/ one/ of/ the/ most/ difficult/ things/ to/ accomplish// Why/ are/ you/ being/ so/ adventurous//?

Jc: I/ like/ being/ very/ ambitious/ and/ unique// and/ I/ like/ blowing/ people/ away/with/ my/ food//

GR: (eat the dish) Uh/ Jack/ I'm// I'm/ lost/ for/ words/ young/ man//

The realization of politeness strategies in data (12) is marked by the positive politeness with use in-group identity sub strategy as shown by the bold sentence. The speaker wants to show that they have the same interests and wants.

\section{$\underline{\text { Positive Politeness - seek agreement }}$}

(13) This is a conversation between Gordon Ramsay and Troy (Tr), 12 years old, in elimination of Masterchef Junior US season $1,6^{\text {th }}$ episode. He cooked a chicken thigh with romesco sauce.

GR: Wow/ So/ Troy/ what/ is/ that//?

Tr: A/ pan-fried/ chicken/ thigh/ with/ romesco/ sauce/ and/ spaghetti/ squash/ and/ zucchini/ salad//

GR: Visually/ it/ looks/ beautiful// I/ was/ slightly/ concerned/ it/ was/ all/ gonna/ look/ slightly/ beige-y/ but/ you've/ got/ that/ vibrancy/ from/ the/ sauce//

Tr: Thank/ you//

GR: What's/ around/ the/ outside/ here//?

Tr: Um/ that's/ herb/ oil/ with/ olive/ oil/ parsley/ and/ a/ little/ cilantro/ in/ there//
GR: (eat the garnish and the sauce) Wow// that/ sauce/ is/ so/ fresh// so/ delicious/ got/ that/ vibrancy// It's/ got/ that/ richness/ to/ it// and/ how/ long/ did/ you/ cook/ the/ chicken/ for//?

Tr: I/ cooked/ it/ about/ four/ minutes/ on/ each/ side/ in/ the/ sauté/ pan/ and/ then/ I/ put/ it/ in/ the/ oven/ and/ baked/ it/ for/ about/ seven/ minutes//

GR: Now/ slice/ that/ through/ (slice the chicken) $\mathrm{Oh} /$ dear//

Tr: What//?

GR: Damn/ damn/ damn/ damn/ damn// I/ can't/ even/ taste/ the/ side/ of/ it/ because/ you/ can/ see/ it's/ still/ raw//

Tr: Yes/ I/ know//

The realization of politeness strategies in data (13) is marked by the positive politeness with seek agreement sub strategy as shown by the bold sentence. The speaker wants to show how bad the food is, but to save the hearer's face, he seeks an agreement to the hearer.

Positive Politeness - Give gifts to $\mathrm{H}$ (sympathy, understanding, cooperation)

(14) This is a conversation between Gordon Ramsay (GR) and Molly (M), 12 years old, in elimination test of Masterchef Junior Season 1, $2^{\text {nd }}$ episode. She cooked a korean BBQ burger with kimchi and fried onion.

GR: What's/ in/ there//?

M: It's/ a/ Korean/ barbecue/ burger/ with/ kimchi/ fried/ onions/ togarashi/ fries/ and/ a/ little/ bit/ of/ slaw//

GR: (eat the burger) Wow/ I/ love/ your/ tenacity// you/ know/, you're/ fearless// But/ the/ patty/ is/ slightly/ dry// the/ season's/ way/ off/ balance/ and/ the/ kimchi//? Yeah/ that/ doesn't/ 


\section{really/ work// However/ it's/ a/ gallant/ effort// Thank/ you//}

The realization of politeness strategies in data (14) is marked by the positive politeness with give gifts to $\mathrm{H}$ (sympathy, understanding, cooperation) sub strategy as shown by the bold sentence. The speaker wants to save the speaker positive face by giving her a gift (understanding, sympathy) although the food is not good enough.

\section{CONCLUSION}

Based on the data above, it can be concluded that Gordon Ramsay performs bald on-record, positive politeness, and off record strategies to the Masterchef and Masterchef Junior contestants. Positive politeness strategies is the most frequent strategies performed by Gordon Ramsay in both show. However, there is difference strategies performed by Gordon Ramsay in both show. Ramsay performed more variations of politeness strategies in Masterchef; on the contrary, Ramsay only performed positive politeness strategy in Masterchef Junior. He prefers to save Masterchef Junior contestants' positive face because a direct critique could influence their motivation in cooking.

\section{ACKNOWLEDGMENTS}

We would like to express our sincere gratitude to journal bahasa \& sastra for publishing this article, and the same goes to those who have helped this research.

\section{REFERENCES}

Anjarsari, S. (2011). "Politenes strategies of criticizing a study on the ugly truth movie". A Thesis of Sebelas Maret University.
Brown, F., \& Levinson, S. (1987). Politeness: Some Universals in Language Usage. New York: Cambridge University Press.

Dailymail.co.uk. (2007, June 5). "How Gordon Ramsay made a grownman cry on America TV". Retrieved June 10, 2014, from Mail online: www.dailymail.co.uk

Green, J. (2007, February). "A guide to using qualitative research methodology". Retrieved May 6, 2013, from Medecins sans frontieres artze ohne grenzen: http://evaluation.msf.at/fileadmin/ evaluation/files/documents/resour ces_MSF/MSF_Qualitative_Meth ods.pdf

Mu, X. Y. (2014). "Redressive strategies for FTA in oprah winfrey's talkshow". Sino-US English Teaching, 11 (5), 380-386.

Safavi, M., \& Zamanian, M. (2014). "Investigating the effect of gender, age, education, and status on distribution of politeness strategies in persian requestive speech acts". International journal of language learning and applied linguistics world (IJLLALW), 7(2), 127-135. Retrieved November 24, 2014

Senowarsito. (2013). "Politeness strategies in teacher-student interaction in an EFL classroom context". TEFLIN Journal, 24 (1), 83-96.

Thomas, J. (1995). Meaning in interaction: An introduction to pragmatics. New York: Longman Publishing. 
Utami, P. W., Darmayanti, N., \& Riyanto, S. (2013). "Expressive speech act of judges' narratives in $\mathrm{x}$-factor indonesia talent show on RCTI: A pragmatic study". International journal of language learning and applied lingustics world (IJLLALW), 4(4), 543-561.

Wikipedia. (2014). Masterchef. Retrieved May 5, 2014, from Wikipedia the free encyclopedia: http://en.wikipedia.org/wiki/Maste rChef

Wise, L. E. (2011). "Speech acts and politeness in spanish and english magazine advertising". A thesis of University of Georgia. 